\title{
Sejarah Pembinaan terhadap Suku Anak Dalam di Kabupaten Batanghari Provinsi Jambi (1970-2014)
}

\author{
Ferry Yanto \\ Program Studi Pendidikan Sejarah FKIP UNBARI \\ email: verryantig0@gmail.com
}

\begin{abstract}
Abstrak: Fokus permasalahan dalam penelitian ini adalah menganalisis proses pembinaan yang dilakukan oleh Pemerintah dan LSM. Fenomena alih fungsi hutan yang dijadikan lahan perkebunan besar kelapa sawit telah menghilangkan sumber mata pencarian masyarakat Suku Anak Dalam yang sebagian besar menggantungkan hidupnya pada hasil hutan. Alih fungsi lahan juga menyebabkan sebagian Suku Anak Dalam keluar dari wilayah jelajah asalnya dan menjadikan SAD terpecah-pecah dan membentuk kelompok dengan identitas baru. Penelitian dilakukan dengan menggunakan metode penelitian ilmu sejarah dengan pendekatan sosial-budaya. Penggunaan teori pembangunan sangat dibutuhkan untuk mendukung penulisan tesis ini. Dari hasil penelitian ditemukan bahwa dampak dari pembinaan dan akibat alih fungsi hutan yang dijadikan sebagai lahan perkebunan besar kelapa sawit dan pemukiman para transmigran pada masa Orde Baru telah merubah sebagian masyarakat SAD untuk mengalihkan mata pencariannya, merubah pola fikir, melapaskan tradisi dan budaya asalnya dan membentuk sebuah identitas baru. Setelah memasuki masa Otonomi Daerah, masyarakat SAD yang awalnya diam dan menerima segala kebijakan yang datang dari Pemerintah Pusat, kini menjadi pribadi yang keras dan menentang segala ketidakadilan yang pernah dilakukan Pemerintah Orde Baru. SAD mulai menuntut hak-hak adatnya dalam bentuk tanah ulayat yang berimbas kepada Pemerintahan berikutnya.
\end{abstract}

Kata Kunci: Pemerintah, Pembinaan, SAD

Abstract: The focus of the problem in this study is to analyze the coaching process carried out by the Government and NGOs. The phenomenon of forest conversion into large oil palm plantations has eliminated the source of livelihoods of the SAD community, which largely depends on forest products. Transfer of land functions also caused some SAD out of their original home range and made SAD fragmented and formed groups with new identities. The study was conducted using historical research methods with a socio-cultural approach. The use of development theory is needed to support the writing of this thesis. From the results of the study it was found that the impact of the formation and effect of the conversion of forest functions which were used as large oil palm plantations and settlements of transmigrants during the New Order changed some SAD communities to shift their livelihoods, change their mindset, broaden their traditions and culture of origin and shape their origin a new identity. After entering the period of Regional Autonomy, the SAD people who were initially silent and accepted all the policies that came from the Central Government, now become a tough person and oppose all the injustices that were perpetrated by the New Order Government. SAD began to demand customary rights in the form of customary land which affected the next Government.

Keywords: Government, Development, SAD

\section{PENDAHULUAN}

Propinsi Jambi merupakan salah satu kawasan di Sumatera yang mempunyai nilai strategis di sektor kehutanan. Sejak dikeluarkannya Undang-Undang No. 1 Tahun 1967 Tentang Penanaman Modal Asing (PMA) memudahkan para pemilik modal untuk masuk ke Jambi. Kebijakan pada masa Pemerintahan Orde Baru telah melahirkan para pemodal besar untuk bebas merambah dan menghancurkan hutan yang ada di pedalaman Propinsi Jambi. Keadaan tersebut juga semakin diperparah dengan masuknya perusahaan besar milik swasta maupun pribadi yang bergerak di sektor perkebunan kelapa sawit.

Pembukaan perkebunan kelapa sawit yang banyak terjadi pada masa Orde Baru ternyata menyimpan banyak masalah, antara lain masalah penggunaan tanah ulayat tanpa persetujuan masyarakat adat, proses penerbitan Hak Guna Usaha (HGU) yang tidak mengikuti ketentuan yang berlaku, sehingga menimbulkan konflik sosial. Menurut catatan akhir tahun 2013 di Propinsi Jambi terdapat 21 kasus konflik sosial yang dialami oleh masyarakat adat termasuk SAD dan 12 kasus konflik sosial antara petani dan perusahaan. Masalah ini sama seperti yang terjadi di Kabupaten Batang Hari yang kawasannya banyak dijadikan sebagai lahan perkebunan kelapa sawit, termasuk sebagian kawasan yang menjadi hunian masyarakat SAD.

SAD kelompok Batin 9 misalnya, mengklaim bahwa kawasan hidup yang diakui sebagai tempat tinggal mereka telah diserobot perusahaan perkebunan sawit milik swasta yakni PT. Asiatic Persada, padahal masyarakat SAD jauh lebih dulu berada dan menghuni di sekitar kawasan perkebunan sawit yang telah disulap menjadi sebuah perusahaan besar tersebut. Kabupaten Batang Hari merupakan salah satu Kabupaten yang memiliki jumlah populasi SAD yang cukup besar, menurut data statistik Kabupaten Batang Hari tahun 2010, masyarakat SAD berjumlah sebanyak 864 Kepala Keluarga (KK), dengan total keseluruhan yakni 
sebanyak 3.895 Jiwa. Masyarakat SAD tersebar di 8 Kecamatan yang berada di peta wilayah administratif Kabupaten Batang Hari.

SAD secara umum hidup dengan mengandalkan hasil hutan, pada tahun 2000, luas hutan di Propinsi Jambi hanya tinggal berkisar 1,6 juta hektar, dari jumlah total luas keseluruhan pada tahun 1990 yakni 2,4 juta hektar. Artinya laju kerusakan hutan di Propinsi Jambi yang terjadi sejak tahun 1970an hingga tahun 2000 semakin meningkat. Kerusakan hutan akibat penebangan dalam bentuk Hak Penguasaan Hutan

$(\mathrm{HPH})$, dan akibat penanaman perkebunan kelapa sawit dengan skala besar di Kabupaten Batang Hari mengharuskan masyarakat SAD tersingkir dari wilayah

jelajah asalnya.

Hingga awal 2015 nasib SAD seakan tidak pernah lepas dari kesengsaraan. Fenomena kematian 11 orang SAD merupakan salah satu bukti bahwa Pemerintah selama ini telah abai terhadap kelangsungan hidup mereka. Terkait hal tersebut Pemerintah selama ini berdalil bahwa SAD yang meninggal tersebut diduga tidak mendapatkan asupan pangan dan air bersih yang layak sehingga mereka sakit dan akhirnya meninggal dunia. Kematian beruntun menyerang di dua Kabupaten yang menjadi daerah persebaran masyarakat SAD yaitu: Kabupaten Batang Hari dan Sarolangun. Korban tersebut merupakan SAD yang berasal dari tiga kelompok Tumenggung antara lain: kelompok Tumenggung Marituha, Tumenggung Ngamal dan Tumenggung Nyenong. Kebijakan yang pernah dijalankan oleh Pemerintah Indonesia sejak tahun 1970an ternyata tidak mampu mengentaskan masalah yang dialami oleh SAD. Lantas, mengapa Pemerintah merasa perlu membentuk kebijakan bagi SAD.

Salah satu kebijakan yang diperuntukkan bagi SAD dinamakan dengan istilah PKSMT atau Program Kesejahteraan Sosial Masyarakat Terasing. Tujuan Pemerintah mengambil kebijakan tersebut dilandasi anggapan dasar bahwa SAD telah kehilangan kontak dengan arus perubahan umum (mainstream) dari sisi sosial, religi, politik dan ekonomi. Kondisi tersebut mendorong Pemerintah untuk terus melakukan berbagai model pembinaan terhadap masyarakat SAD dengan cara memasukkan ke dalam tatanan masyarakat umum, melalui pemberian bantuan rumah atau pemukiman, mengenalkan cara-cara berproduksi, mengenalkan budaya baru, pendidikan formal, fasilitas kesehatan, pemberian agama, dan mengajarkan untuk berinteraksi dengan masyarakat lain.

Hasil akhir dari model pembinaan yang dijalankan tersebut, diharapkan mampu merubah tatanan kondisi sosial masyarakat SAD yang dianggap primitif oleh Pemerintah Orde Baru yang ketika itu dipimpin oleh Presiden Soeharto yang dijuluki sebagai Bapak Pembangunan. Selain kebijakan di sektor kehutanan, perkebunan skala besar, dan PKSMT, kebijakan transmigrasi secara besar-besaran juga diberlakukan oleh Pemerintahan Orde Baru. Pada periode 1980an, Pemerintah memindahkan penduduk Jawa ke seluruh wilayah Kabupaten Batang Hari, dengan dukungan dana dari Bank Dunia (World Bank) demi pertumbuhan ekonomi yang dikenal sentralistis.

Program PKSMT dan transmigrasi pada dasarnya merupakan kepentingan Pemerintah untuk merubah kondisi sosial SAD baik secara langsung maupun tidak langsung, dan tentunya kepentingan tersebut telah terjalin antara penguasa dan pengusaha untuk merampas bagian yang tidak dapat dipisahkan dalam kehidupan SAD yaitu hutan.

Pada era 1990an. Pemerintah mengklaim bahwa telah berhasil membina masyarakat SAD di Kabupaten Batang Hari dalam berbagai model yang telah direncanakan dan ditentukan. Jumlah SAD yang telah dibina dan dimukimkan mencapai angka yang sangat fantastis yaitu sebanyak $2.744 \mathrm{KK}$ atau 12.185 Jiwa. SAD yang telah terbina tersebut dikenalkan dan diajarkan cara-cara bertani, dengan harapan kedepan dapat menjadi seorang petani handal, dan diharapkan dapat mendukung program pembangunan nasional yang telah direncanakan Pemerintah Orde Baru.

Program pembinaan yang pernah dilakukan oleh Pemerintah Orde Baru terhadap SAD menarik perhatian penulis untuk diteliti lebih lanjut. Indikator keberhasilan yang tunjukkan oleh Pemerintah tidak cukup hanya sampai pada tingkat memukimkan SAD saja, melihat di beberapa daerah seperti di TNBD masyarakat SAD di sekitar lokasi tersebut selalu gagal untuk dimukimkan dan dibina, hal tersebut disebabkan keterikatan SAD untuk selalu mempertahankan tradisi dan budaya yang dianggap sebagai warisan nenek moyang mereka.

Bagaimana sesungguhnya model pembinaan yang dilakukan Pemerintah pada masa Orde Baru terhadap SAD, dan bagaimana model serta dampak pembinaan di masa Otonomi Daerah yang mulai 
melibatkan Lembaga Swadaya Masyarakat (LSM) terhadap SAD. Historisitas pembinaan yang dilakukan oleh Pemerintah dan LSM terhadap masyarakat SAD menarik perhatian penulis untuk diteliti lebih lanjut. Untuk itu penelitian ini difokuskan pada masyarakat SAD yang belum maupun telah terbina oleh Pemerintah maupun LSM. Judul yang dipilih dalam penelitian ini adalah: "Sejarah Pembinaan Terhadap SAD di Kabupaten Batang Hari Propinsi Jambi 1970-2014”.

\section{METODE PENELITIAN}

Penelitian ini menggunakan metode penelitian ilmu sejarah, dengan pendekatan sosial-budaya, melalui empat tahapan yaitu pengumpulan sumber (heuristik) berupa studi dokumenter dan lapangan, pengujian (kritik), interpretasi dan penulisan (historiografi). Tahapan pertama, dalam pengumpulan sumber dilakukan melalui proses pencarian dan pengumpulan sumber tertulis berupa arsip laporan "Pola Pembinaan Masyarakat Terasing SAD di Wilayah Kabupaten Batang Hari", Laporan Data Base warga SAD di Kecamatan Bajubang, kemudian Laporan berita acara penyerahan sertifikat program KAT di Kabupaten Batang Hari, dan Daftar Laporan Jumlah Kepala Keluarga dan Anggota Keluarga Masyarakat Terasing SAD yang telah dibina dan sedang dibina. Data tersebut diperoleh dari Dinas Sosial Tenaga Kerja dan Transmigrasi Kabupaten Batang Hari. Pengumpulan sumber tertulis lainya berupa data statistik jumlah masyarakat SAD yang dibina dan belum dibina oleh Pemerintah dari tahun 1980, 1984, 1991, 1994 dan 2010 yang di dapat dari kantor BPS Kabupaten Batang Hari. Sumber tertulis lain berupa catatan pendampingan dan bulletin milik lembaga non Pemerintahan yakni Warsi. Warsi ikut berpartisipasi mendampingi SAD di Kabupaten Batang Hari sejak tahun 1998. Tahap berikutnya dalam penelitian ini berupa pengumpulan sumber lisan yang diperoleh melalui wawancara. Wawancara dilakukan dengan pola tidak terstruktur dari menemui informan satu, bergulir ke informan lain yang menjadi tokoh kunci dan dapat dipercaya dalam memberikan informasi maupun keterangan terkait penelitian ini.

\section{HASIL DAN PEMBAHASAN}

\section{Sejarah Awal Pembinaan Masa Orde Baru}

Kabupaten Batang Hari Sejak awal Orde Baru tahun 1970 merupakan salah satu Daerah Tingkat II dalam wilayah Provinsi Jambi dengan luas wilayah 11.200,00 Km². Jumlah penduduknya pada tahun 1971 sebanyak 158.730 jiwa, kemudian pada tahun 1980 meningkat menjadi 216.655 jiwa. Dari jumlah penduduk tersebut, tersebar di enam kecamatan dan 166 desa. Kecamatan tersebut antara lain: Kecamatan Mersam, Kecamatan Muara tembesi, Kecamatan Muara Bulian, Kecamatan Jambi Luar Kota, Kecamatan Sekernan dan Kecamatan Kumpeh. Berdasarkan UU. No 7 Tahun 1965 Kabupaten Batang Hari dimekarkan menjadi dua daerah yaitu Kabupaten Batang Hari yang pada tahun 1970 sampai tahun 1999 ibu kotanya Kenali Asam dan Kabupaten Tanjung Jabung yang beribu kota Kuala Tungkal.

Pembangunan di Indonesia telah dilaksanakan secara intensif sejak sekitar 30 tahun melalui Pembangunan Jangka Panjang (PJP) pertama selama 20 tahun dan PJP kedua yang dilaksanakan melalui Pembangunan Jangka Menengah (PJM) yaitu Rencana Pembangunan Lima Tahun (Repelita). Repelita I dimulai pada tahun 1967/1968 sampai dengan 1972/1973 dan setiap lima tahun dilanjutkan dengan Repelita berikutnya sampai pada pelaksanaan Repelita VI yang berakhir pada tahun 1998 pada saat dimulainya reformasi di bidang politik, sosial dan ekonomi. Arah kebijaksanaan pembangunan selama masa pembangunan tersebut dikenal sebagai trilogi pembangunan, terdiri dari tiga aspek yaitu pemerataan, pertumbuhan dan stabilitas keamanan.

Urutan prioritas trilogi pembangunan tersebut berganti-ganti seiring dengan perkembangan sosial, ekonomi, dan politik. Namun selama kurun waktu lebih dari 30 tahun tersebut, dapat dirasakan bahwa pertumbuhan ekonomi lebih mendapat perhatian dibanding pemerataan, sedangkan keamanan mendapat prioritas pada masa awal pembangunan, mengingat kondisi sosial dan politik pada saat itu. Pembangunan ekonomi dan prasarana fisik yang menjadi alat bagi pencapaian pertumbuhan, dilaksanakan melalui pendekatan pembangunan sektor-sektor ekonomi dengan sektor pertanian dan industri yang menjadi motor penggeraknya. Pelaksanaan pembangunan yang menekankan pada pembangunan sektoral ini cukup berhasil bagi peningkatan pertumbuhan ekonomi.

Pada aspek pemerataan kesejahteraan, mulai mendapatkan perhatian Pemerintah pada awal tahun 1974an. Pemerintah mulai memberlakukan kebijakan dibidang kesejahteraan yang merupakan salah satu 
upaya perwujudan pencapaian tujuan dari pembangunan nasional. Menurut buku pedoman Depatemen Sosial RI yang berjudul "Pola Dasar Pembangunan Bidang Kesejahteraan Sosial "menyatakan bahwa pendekatan dasar pembangunan bidang kesejahteraan sosial meletakkan titik sentral pada manusia dan lingkungan sosialnya. Salah satu kebijakan tersebut menjelaskan tentang penanganan masyarakat terasing. Masyarakat terasing merupakan masyarakat yang belum sepenuhnya terjangkau oleh proses pelayanan pembangunan, baik karena isolasi alam maupun isolasi sosial budaya. Masyarakat terasing dianggap dapat menghambat proses pemerataan pembangunan, karena tidak sesuai dengan cita-cita pemerintah yang ingin menuju kearah tercapainya keadilan sosial bagi seluruh rakyat Indonesia.

Berbagai alasan inilah sehingga perlunya Pemerintah untuk melakukan pembinaan terhadap masyarakat terasing khususnya SAD. Pembinaan masyarakat terasing SAD di Propinsi Jambi telah dilakukan sejak tahun 1954 dengan beberapa tahapan atau fase, yaitu:

1. Fase pertama, tahun 1954-1967, kegiatannya meliputi bidang riset dan pilot proyek di lokasi Senami Kabupaten Batanghari dan di Kabupaten Sarolangun Bangko.

2. Fase kedua, tahun 1967-1972, kegiatannya hanya dilakukan dalam bentuk Pusat Operasional Sementara (POS) dengan kegiatan pokok inventarisasi dan motivasi.

3. Fase ketiga, tahun 1972-1995 kegiatannya adalah pembinaan melalui proyek pembinaan kesejahteraan sosial masyarakat terasing (PKSMT) dengan pendekatan permukiman ex-situ.

4. Fase keempat, tahun 1995-1999 kegiatannya adalah pembinaan dengan pendekatan in-situ.

5. Fase kelima, sejak tahun 1999 hingga sekarang mulai melakukan pendekatan pemberdayaan masyarakat yang disebut dengan Pembinaan Kesejahteraan Masyarakat Terasing (PKSMT). Di Jambi, istilah PKSMT belum banyak diketahui oleh masyarakat. Masyarakat lebih familier dengan istilah proyek pemukiman kembali SAD (Kubu).

Pada fase ke satu dan dua peranan Pemerintah terhadap masyarakat terasing SAD belum terlalu terlihat. Pada tahun 1972 Pemerintah mulai fokus menangani masalah yang dihadapi oleh SAD. Agenda khusus yang menangani masalah SAD diatur dalam undang-undang nomor 6 Tahun 1974. Tentang ketentuan pokok kesejahteraan sosial, yang menyatakan bahwa setiap warga negara berhak atas taraf kesejahteraan sosial yang sebaik-baiknya dan berkewajiban untuk sebanyak mungkin ikut serta dalam usahausaha kesejahteraan sosial, maka penanganan Pembinaan Kesejateraan Masyarakat Terasing perlu dilaksanakan secara berencana, terarah, terpadu dan berkesinambungan sehingga tidak terdapat lagi kelompok-kelompok masyarakat di Indonesia yang tidak terjangkau oleh proses pelayanan pembangunan.

\section{Strategi dan Pendekatan dalam Upaya Pembinaan}

Program Pembinaan Kesejahteraan Masyarakat Terasing (PKSMT) merupakan salah satu program pemerintah dibidang sosial yang menjadikan masyarakat terasing sebagai sasarannya, yang tentunya Pemerintah berniat untuk meningkatkan kesejahteraannya. Niat baik tersebut didasarkan pada kondisi ekonomi, sosial, budaya masyarakat terasing yang dirasakan oleh pemerintah sangat lamban dalam perkembangannya diihat dari sisi dan sudut pandang perbandingan dengan masyrakat Indonesia lainnya yang begitu cepat berubah menuju kearah kemajuan.

Kelambanan masyarakat SAD untuk berubah disebabkan oleh berbagai faktor baik dari dalam maupun dari luar seperti desakan para pendatang yang memiliki kekuatan dominan dalam kekuasaan dan kebudayaan, keinginan untuk mempertahankan kebudayaan sendiri, keterisoliran geografis, dan distribusi pembangunan yang belum merata. Keragaman tingkat adaptasi masyarakat SAD untuk berubah membutuhkan suatu pemahaman yang didasarkan pada studi-studi kebudayaan.

Untuk itu Pemerintah melalui Departemen Sosial mulai melakukan studi-studi kebudayaan yang melalui strategi dan pendekatan etnografi. Langkah untuk memanfaatkan etnografi diambil sebagai dasar dalam mengambil kebijakan yang sudah dilakukan oleh Direktorat Bina Masyarakat Terasing melalui berbagai kegiatan Pengkajian Sosial Budaya dan Lingkungan (PSBL) yang bertujuan untuk menemukenali ciri-ciri sosial budaya dan berbagai potensi yang dimiliki oleh warga masyarakat terasing dalam konteks ini adalah masyarakat SAD yang merupakan salah satu sasaran target dalam PSBL.

Program PKSMT di Kabupaten Batang Hari secara umum dimulai sejak tahun 1974. Strategi awal yang dilakukan oleh Pemerintah pada tahun 1972an adalah dengan melakukan pengamatan dan pendataan terhadap keberadaan masyarakat terasing SAD. Salah seorang informan dari Departemen Sosial (Depsos) 
yang pernah terlibat dalam pendataan PKSMT menjelaskan bagaimana proses pendataan waktu itu masih sulit dilakukan, dikarenakan keberadaan SAD pada saat itu masih sulit diidentifikasikan secara keseluruhan, karena keberadaan SAD saat dilakukannya pendataan ada yang sudah menetap sementara, dan ada juga beberapa kelompok SAD hidupnya sedang berpindah-pindah (kelana) dari hutan satu ke hutan yang lain, dan tidak seperti sekarang mereka sudah banyak yang menetap.

\section{Pengkajian Calon Lokasi Pembinaan (PCLP)}

Perlunya pembinaan terhadap masyarakat terasing SAD adalah komitmen awal Pemerintah untuk mengejar ketertinggalan SAD dalam proses pembangunan dan mengentaskan masalah kemiskinan terhadap sendi kehidupan mereka, walaupun sebenarnya masalah kemiskinan merupakan masalah yang kompleks dalam kehidupan setiap manusia. Pengajian Calon Lokasi Masyarakat Terasing (PLCP) merupakan program lanjutan pemerintah dari program-program yang pernah ada sebelumnya.

PLCP pada dasarrnya merupakan studi etnografi, yaitu suatu studi yang mempelajari dan menjelaskan kebudayaan suatu masyarakat tertentu. Studi etnografi dibutuhkan dalam rangka pemahaman dan penjelasan kehidupan sosial budaya masyarakat SAD serta keterkaitannya dengan perencanaan program pembangunan. Dengan data yang diperoleh melalui studi semacam ini maka perencanaan dan pelaksanaan program pembangunan masyarakat terasing dapat:

1. Melihat permasalahan masyarakat SAD sebagai suatu sistem yang mempunyai sejumlah unsur atau pranata kebudayaan yang satu dengan yang lainnya yang saling berkaitan.

2. Dapat memberikan pembinaan yang sesuai dengan kebutuhan kelompok sasaran.

3. Dapat memperhitungkan akibat dari perubahan yang disebabkan oleh program pembangunan tertentu, bagi kelompok sasaran sehingga tidak akan terjadi dampak-dampak yang justeru menurunkan tingkat kesejahteraan masyarakat SAD.

Berbagai kegiatan pembinaan kesejahteraan masyarakat terasing seharusnya dapat menjamin, keselamatan hidup manusia itu sendiri, penyediaan sumber daya makanan, penyediaan tempat untuk mengembangkan keturunan, menciptakan arena untuk mengaktualisasikan diri dan mengembangkan kreativitas, dan yang terakhir mewujudkan media sosial guna mengembangkan kesetiakawanan kelompok sosial yang bersangkutan, dan bukan malah menimbulakan keadaan yang sebaliknya. Kenyataan dilapangan kegiatan seperti ini pada umumnya tidak selalu berjalan mulus dalam setiap perjalanan kegiatan program.

Pemerintah Indonesia menyadari adanya permasalahan diatas, melalui Departemen Sosial, telah melakukan kegiatan-kegiatan untuk mengembangkan taraf kehidupan sosial dan ekonomi mereka serta kebudayaan dari masyarakat-masyarakat terasing yang ada di Indonesia. Kegiatan-kegiatan tersebut telah dilakukan sejak tahun 1950an dan masih terus berlangsung hingga sekarang. Kegiatan-kegiatan tersebut dinamakan re-lokasi, pemukiman suku terasing, pemukiman masyarakat terasing, pemukiman untuk kesejahteraan masyarakat terasing. Walaupun nama-nama kegiatan tersebut berbeda satu sama lain tetapi pada dasarnya mempunyai tujuan dan pola-pola kegiatan yang sama, yaitu bertujaun untuk mengelompokkan mereka yang hidup tersebar-sebar dalam wilayah yang luas kedalam sebuah pemukiman menetap yang mempunyai corak sebagai sebuah desa atau bagian desa (dusun, dukuh atau RW dan RT), mengatur tata kehidupan mereka dalam pemukiman tersebut berdasarkan aturan-aturan administrasi desa, memberikan pengetahuan, keterampilan dalam hal pertanian, peternakan, perikanan, kerajinan tangan, kesehatan dan kesejahteraan keluarga dan agama, serta pendidikan sekolah bagi anak-anak mereka.

\section{Pemukiman (resettlement)}

Pemukiman yang dibangun dan diperuntukkan khusus bagi masyarakat SAD merupakan salah satu cara dan strategi yang digunakan oleh Pemerintah melalui Depsos. Dengan pendekatan seperti ini maka diharapkan yang terjadi adalah indikasi-indikasi keberhasilan dan lingkup pembangunannya (aspek fisik dan non fisik) yang telah ditentukan oleh pemerintah. Dan indikasi keberhasilan yang paling menonjol, terlihat dan dapat dihitung peningkatannya atau dikuantifikasikan adalah "pemukiman" karena hasil akhirnya berupa desa pemukiman, jumlah rumah, jumlah penduduk yg dimukimkan, jumlah masyarakat yang memeluk agama resmi, yang kesemuanya adalah data-data yang berwujud angka-angka statistik. Program pemukiman merupakan jurus handal bagi penggiat pembinaan. 
Porsi indikator pemukiman ini cukup dominan dibandingkan oleh indikasi keberhasilan sosial lain. Pemukiman seperti menjadi semacam "entry point" dan cakupan nilai keberhasilan seluruh hasil pembangunan. Yang menjadi sasaran utamanya adalah masyarakat terasing dengan skala prioritas terbesar adalah "masyarakat setengah-kelana" (ada 3, yaitu kelana, setengah-kelana dan menetap-sementara). Diharapkan dengan sudah menetapnya masyarakat ini maka akan bisa menyerap masyarakat kelana, masyarakat kelananya akan ikut menetap, sehingga ada efek gandanya. Menurut Peneliti, pemerintah melihat kehidupan menetap sebagai suatu bentuk kehidupan yang stabil dan mantap. Ini nampak dalam tujuan pemukiman melalui program pemukiman kembalinya (resettlement) dan pengumpulan masyarakat yang terpencar dalam 1 lokasi yang ditulis sebagai sebuah langkah awal untuk pemantapan sosial, ekonomi dan budaya. Jadi memang, keterpencaran mereka dianggap sebagai suatu masalah sosial juga.

\section{Pengelompokan SAD}

SAD termasuk salah satu kategori masyarakat terasing di Indonesia yang mendapatkan perhatian dari para sosiolog, di antaranya Qyvind (1984), Muntholib (1995), Amilda (1999), Warsi (2000), Ali M.A. Rahman (2000), Wientre (2001), dan sebagainya. Mereka meneliti tentang kehidupan masyarakat SAD di Jambi. Dengan kata lain, para ahli tersebut meneliti kehidupan sehari-hari masyarakat SAD, baik dari kebiasaan cara berburu, adat istiadat, dan sebagainya.

Melihat kondisi SAD seperti yang pernah diteliti oleh para ilmuwan antropolog diatas, pada dasarnya pemerintah Indonesia telah berinisiatif menjalankan program pembangunan masyarakat khususnya menangani masalah keterasingan. Program-program pembangunan lainnya merupakan program pendukung yang tidak bisa dilepaskan keterkaitanya terhadap suatu indikator keberhasilan maupun kegagalan dalam pembinaan masyarakat SAD. Mengingat memasuki tahun 1990an kehidupan SAD di Kabupaten Batang Hari banyak mengalami kemajuan, baik berupa pola interaksi sosial yang lebih terbuka, memiliki pola perladangan tetap, kebiasaan melangun yang mulai ditinggalkan, gaya hidup modern, menggunakan berbagai fasilitas elektronik bahkan sudah mengerti struktur dan birokrasi pemerintahan.

Melihat pola kehidupan SAD yang telah di jelaskan diatas, maka sejarah pembinaan terhadap SAD tidak bisa dilepaskan dari peranan PKSMT dalam upaya pembinaannya. Pemerintah menggolongkan istilah masyarakat terasing kepada dua kelompok yang berbeda, yaitu masyarakat terasing yang berada di daerah pedalaman (hutan) dan yang berada di pesisir (laut). Dalam penelitian ini tidak akan disinggung mengenai masyarakat terasing yang berada dipesisir (laut) dikarenakan fokus penelitian dan sumber data tertulis kepada masyarakat terasing yang berada di Pedalaman.

Berdasarkan keadaan geografisnya masyarakat terasing SAD dikategorikan menjadi tiga kelompok berdasarkan gaya hidup umumnya, masyarakat SAD tersebut dibagi menjadi 3 kelompok: Mengembara, menetap sementara dan menetap. Tabel 1,2 dan 3 dibawah ini menerangkan ciri-ciri masyarakat SAD berdasarkan kategori yang dibina oleh Pemerintah (Depsos) dengan beberapa penglompokan yang telah disebutkan.

Tabel 1. Masyarakat Terasing SAD Melangun/Mengembara/Kelana

\begin{tabular}{cll}
\hline No & \multicolumn{1}{c}{ Kategori } & \multicolumn{1}{c}{ Ciri-ciri } \\
\hline 1 & Melangun/mengembara & $\begin{array}{l}\text { Selama 2-4 tahun peserta melangun/mengembara seluruh anggota keluarga } \\
\text { dan famili, jangkauan mengembara 75 km. }\end{array}$ \\
2 & Pemimpin Tradisional & $\begin{array}{l}\text { Temenggung, depati, mangku, menti dan debalang Batin. } \\
\text { Dipandang sebagai upacara keramat, dipertahankan dan tidak mau ditonton } \\
\text { orang luar. }\end{array}$ \\
3 & Basale & Tidak berladang, tidak punya budaya mengolah tanah. \\
4 & Ladang/huma & Pantang/tidak hidup berdusun tidak punya rumah atap. \\
5 & Tempat Tinggal & Sangat sederhana, sebagai tempat berteduh \\
6 & Rumah/sundung & Kelompok kecil berdasarkan geneologis \\
7 & Kelompok & Berburu, meramu mengumpul. \\
8 & Mata Pencarian & Terbatas dan tertutup, melaui jenang atau induk semang. \\
9 & Interaksi Sosial & Kain sarung, tombak dan golok. \\
10 & Kekayaan & Animisme, dinamisme, polytheisme. \\
11 & Kepercayaan & Strkand
\end{tabular}

Sumber: Muntholib Soetomo, Orang Rimbo: Kajian Struktural dan Fungsional Masyarakat Terasing di Makekal Propinsi Jambi, (UNPAD: Disertasi Doktoral, 1995). 
Tabel 2. Masyarakat Terasing SAD Menetap Sementara/Setengah Kelana

\begin{tabular}{|c|c|c|}
\hline No & Kategori & Ciri-ciri \\
\hline 1 & Melangun/mengembara & Selama 3-6 bulan, peserta seluruh anggota keluarga radius $\pm 25 \mathrm{~km}$. \\
\hline 2 & Pemimpin Tradisional & Sebagian struktur sudah hilang. \\
\hline 3 & Basale & Tidak dikeramatkan, dipertahankan dan dapat ditonton orang luar. \\
\hline 4 & Ladang/huma & Mulai membuka ladang, luas ladang/huma $\pm 1 / 4$ ha. \\
\hline 5 & Tempat Tinggal & Mulai menetap dalam waktu tertentu, lokasi dihuma/ladang. \\
\hline 6 & Rumah/sundung & Sangat sederhana, sebagai tempat berteduh \\
\hline 7 & Kelompok & Kelompok besar dan mulai bergabung dengan etnis lain. \\
\hline 8 & Mata Pencarian & Ladang, kebun karet, berburu dan mengumpul. \\
\hline 9 & Interaksi Sosial & Terbuka. \\
\hline 10 & Kekayaan & Rumah, kebun, kendaraan. \\
\hline 11 & Kepercayaan & Animisme, dinamisme, sebagian islam. \\
\hline Sumber: & \multicolumn{2}{|c|}{$\begin{array}{l}\text { Muntholib Soetomo, Orang Rimbo: Kajian Struktural dan Fungsional Masyarakat Terasing di Makekal Propinsi } \\
\text { Jambi, (UNPAD: Disertasi Doktoral, 1995). }\end{array}$} \\
\hline \multicolumn{3}{|r|}{ Tabel 3. Masyarakat Terasing SAD Menetap } \\
\hline No & Kategori & Ciri-ciri \\
\hline 1 & Melangun/mengembara & Tidak Melangun/mengembara \\
\hline 2 & Pemimpin Tradisional & Sebagian struktur sudah hilang. \\
\hline 3 & Basale & Tidak dikeramatkan, dipertahankan dan dapat ditonton orang luar. \\
\hline 4 & Ladang/huma & Memiliki kebun karet dan sawit. \\
\hline 5 & Tempat Tinggal & Menetap didalam pemukiman, Desa/Dusun \\
\hline 6 & Rumah/sundung & Beraneka ragam \\
\hline 7 & Kelompok & Kelompok besar dan mulai bergabung dengan etnis lain. \\
\hline 8 & Mata Pencarian & Ladang, kebun karet, kerja upah, kuli motong (nyadap karet). \\
\hline 9 & Interaksi Sosial & Terbuka. \\
\hline 10 & Kekayaan & Rumah, kebun, kendaraan. \\
\hline 11 & Kepercayaan & Islam. \\
\hline
\end{tabular}

Sumber : Tim Universitas Jambi bekerjasama dengan Dinas KSPM Jambi, 2005.

Pengelompokan terhadap SAD dimaksudkan Pemerintah untuk mempermudahkan dalam suatu proses pendekatan dilapangan. Perlu diketahui bahwa pada tahun 1975-1993 proses pembinaan di Kabupaten Batang Hari belum menampakkan indikator keberhasilan yang signifikan seperti yang diharapkan pemerintah dengan indikator keberhasilannya yakni dimukimkan dan menjalankan kehidupan seperti masyarakat melayu yang hidup berdampingan dengan mereka, hal ini ditandai dengan beberapa data yang tidak ditemukan saat dilakukannya penelitian. Beberapa petunjuk hanya memberikan keterangan jumlah masyarakat SAD yang secara keseluruhan yang dibina di Kabupaten Batang Hari, dan tidak ada laporan yang khusus mencatat presentase keberhasilan yang dibina tersebut. Justru hasil dari program pembinaan tersebut mulai terlihat pada tahun 1994an setelah pembinaan tersebut diserahkan kepada Pemerintah Daerah setempat.

\section{Perkembangan Pembinaan}

Pada awal tahun 1975 kegiatan pembinaan terhadap SAD lebih bersifat tunggal yaitu dengan sistem pendekatan ex-situ development atau lebih dikenal dengan istilah pemukiman ditempat baru. Sayangnya pada periode ini tidak ada data yang menunjukkan jumlah pembangunan pemukiman, beberapa laporan pembinaan tentang masyarakat terasing hanya membahas jumlah keseluruhan dari masyarakat terasing SAD, dan selebihnya hanya membahas laporan pengkajian dan cara hidup masyarakat terasing yang tinggal dan berada didaerah yang dikaji. Indikator keberhasilan pada periode ini belum menunjukkan hasil yang memuaskan. Namun secara psikologis pada awal pembinaan warga SAD berada dalam kondisi tertekan dan sulit beradaptasi dengan warga lainnya.

Tidak dapat dipungkiri bahwa sebelum adanya program pembinaan kesejahteraan masyarakat terasing, kehidupan SAD memang sangat bergantung kepada kondisi alam yang ada, secara umum kehidupan mereka masih terpencar, sumber makanan yang mereka dapatkan dengan memanfaatkan hasil hutan dan ditukar dengan kebutuhan mereka sehari-hari seperti gula, kopi, beras garam dan lain-lain. SAD menganut konsep hidup kita harus belajar dari hutan. Merupakan hal yang wajar jika pada proses awal pembinaan, berbagai masalah baru muncul karena perbedaan karakter budaya. 
Salah seorang informan dari Departemen sosial yang pernah terlibat dalam pendataan program PKSMT menjelaskan bagaimana proses pendataan masih sulit dilakukan diawal tahun, dikarenakan keberadaan SAD saat itu masih sulit di identifikasikan secara keseluruhan, karena keberadaan SAD dibeberapa Kecamatan yang ada di Kabupaten Batang Hari masih banyak yang nomaden (kelana/tidak menetap) dari hutan satu ke hutan yang lain, padahal berbagai upaya telah dilakukan agar mereka tertarik untuk dibina, bahkan beberapa rekan kerja informan sering kesal membina masyarakat SAD. Karena seolah-olah mereka harus dimanjakan. Sampai tahun 1985an kehidupan mereka masih sangat bergantung terhadap pemerintah, jika jadub datang mereka akan datang ke pemukiman, jika jadub habis mereka kembali lagi ke hutan.

Memasuki tahun 1990an Pemerintah mulai melakukan dan mengembangkan strategi pembinaan yang beragam guna menghindari terjadinya hal yang serupa saat diawal pembinaan yaitu kembalinya kelompok SAD ke dalam hutan. Proses dalam memukimkan SAD menggunakan pendekatan yang terlihat sedikit modern agar masyarakat SAD bisa betah dan bertahan di pemukiman. Pada tahun 1990 di Kabupaten Batang Hari terdapat 1.348 KK dan 5.957 jiwa. Memasuki tahun 1990an model atau bentuk program pembinaan yang dilakukan oleh Pemerintah di Kabupaten Batang Hari dapat dilihat dari berbagai pendekatan dibawah ini:

1. Program peningkatan sumber daya manusia meliputi:
a. Penempatan petugas sebagai Jenang
b. Pemutaran film dan TV
c. Mengajak SAD rekreasi agar mengenal dunia luar
d. Pengadaan alat komunikasi/informasi elektronik.

2. Program peningkatan pendapatan meliputi:

a. Memberikan bantuan bibit padi lokal, ubi, jagung dan sayuran

b. Penyebaran benih ikan (restocking) di daerah rawa-rawa dan sungai-sungai kecil

c. Memberikan peralatan pertanian berupa parang dan beliung.

3. Program pembinaan Kesejahteraan sosial meliputi:

a. Pengobatan penyakit

b. Bantuan pakaian bagi anak-anak

c. Bantuan jatah hidup (jadup)

d. Memberikan bantuan perlengkapan rumah tangga seperti periuk, kuali, cangkir kaleng, ceret air dan piring kaleng serta jerigen.

4. Program pembangunan prasarana dan sarana fisik meliputi:

a. Pembuatan jalan dan jembatan penghubung

b. Pembuatan tempat-tempat istirahat

c. Pembuatan pasar kaget (pasar tiban) untuk penjualan/penukaran hasil pencarian mereka

d. Pembuatan perumahan paramedis dan satgassos.

Beberapa program penanganan masyarakat terasing SAD pada dasarnya mempunyai model atau bentuk yang sama, antara daerah yang satu dengan daerah yang lainnya, baik di tingkat Desa maupun di tingkat Kecamatan yang ada di Kabupaten Batang Hari, tergantung dari situasi dan kondisi alam masingmasing daerah yang akan dibina. Model pembinaan yang sama tersebut dimaksudkan oleh pemerintah untuk mempermudah dalam proses pelaksanaan pembanggunan sehingga nantinya tidak menimbulkan berbagai perbedaan yang dapat menimbulkan kecemburuan sosial antara daerah satu dan daerah lainnya, khususnya yang ada di kawasan administratif Kabupaten Batang Hari.

Masyarakat terasing yang berada di Kabupaten Dati II Batang Hari atau lebih dikenal dan digolongkan oleh Pemerintah Daerah Tingkat II Batanghari sebagai kelompok SAD, berada dan tersebar di 5 kecamatan pada 20 lokasi. Pada tahun 1994 keberadaan mereka dirincian sebagai berikut:

1. Kecamatan Mestong 7 lokasi meliputi 488 KK (2.040 jiwa)
1.1. Tanjung Lebar
$126 \mathrm{KK}(510$ jiwa)
1.2. Nyogan
75 KK (293 jiwa)
1.3. Pelempang
$75 \mathrm{KK}$ (295 jiwa)
1.4. Jantang Menggeris
$50 \mathrm{KK}$ (221 jiwa)
1.5. Pengeratan
$50 \mathrm{KK}$ (292 jiwa)
1.6. Lubuk Rengis
50 KK (197 jiwa) 
1.7. Bunut Merkanding

$62 \mathrm{KK}(232$ jiwa)

2. Kecamatan Muara Bulian 4 lokasi meliputi $289 \mathrm{KK}$ (1. 458 jiwa)
2.1. Bungku
2.2. Ladang Peris
$50 \mathrm{KK}(297$ jiwa)
$50 \mathrm{KK}(292$ jiwa)
2.3. Muara Singoan
$150 \mathrm{KK}$ (750 jiwa)
2.4. Sialang Punguk
39 KK (119 jiwa)

3. Kecamatan Muara Tembesi 3 lokasi meliputi $160 \mathrm{KK}$ (658 jiwa)
3.1 Bukit Tembesu I
3.2. Bukit Tembesu II
$75 \mathrm{KK}$ (327 jiwa)
3.3. Bukit Tembesu III
$45 \mathrm{KK}(225$ jiwa $)$
$40 \mathrm{KK}(133$ jiwa)

4. Kecamatan Batin XXIV 4 lokasi meliputi 260 KK (1.280 jiwa)

4.1. Bungin Panjang

4.2. Paku Aji

$75 \mathrm{KK}(327$ jiwa)

4.3. Aur Jangga

$115 \mathrm{KK}(603$ jiwa)

$70 \mathrm{KK}(350$ jiwa)

4.4. Sepangan / Hajran

$12 \mathrm{KK}$ (47 jiwa)

5. Kecamatan Perwakilan Maro Sebo Ulu 2 lokasi meliputi 139 KK (547 jiwa)
5.1. Sungai Kejasung
$67 \mathrm{KK}(298$ jiwa)
5.2. Batu Sawar (Sungai Terap)
$72 \mathrm{KK}(249$ jiwa).

Keterasingan menimbulkan dampak keterbelakangan dan ketertinggalan dalam seluruh aspek kehidupan masyarakat terasing tersebut. Dampak keterasingan dapat dilihat dari berbagai indiator antara lain: kondisi yang sangat rendah dibidang kesehatan, pendidikan, gizi, tempat tinggal, sandang dan interaksi sosial dengan masyarakat lainnya disamping itu sebagian tradisi mereka kurang mendukung pembaharuan dan pembangunan, bahkan cenderung bersifat tertutup.

\section{Transmigrasi Sebagai Solusi Alternatif}

Tidak dapat dipungkiri dari berbagai paradigma pembangunan pada masa Orde Baru melahirkan berbagai program-program yang berkaitan erat sebagai pendukung antara program yang satu dan program lainnya. Bahkan beberapa program yang ada sekarang sebagian besar masih merupakan sisa produk Orde Baru, bahkan konsep dalam setiap pelaksanaannya pemerintahan masih menggunakan cara-cara lama tersebut. Salah satu program yang memiliki pengaruh besar dalam perubahan sosial dan kebudayaan bagi SAD di Kabupaten Batang Hari adalah program Transmigrasi.

Pada periode rencana pembangunan lima tahun (repelita) ke-2 antara tahunn 1974-1979, konsep transmigrasi diintegrasikan ke dalam pembangunan nasional. Dalam kerangka pembangunan nasional tersebut, transmigrasi diharapapkan dapat meningkatkan ketahanan nasional, baik di bidang ekonomi, sosial, maupun budaya, serta meningkatkan produksi pangan dan komoditi eksport.

\section{Pembinaan Masa Otonomi daerah dan Respon SAD terhadap Pembinaan}

Upaya pembinaan terhadap SAD pada awal-awal tahun setelah berlakunya kebijakan tahun 1974 menjadi tugas dan tanggung jawab yang tidak mudah untuk dilakukan bagi pemerintah yang terkait dan berwenang dalam menangani masalah keterasingan yang dialami oleh SAD, berbagai faktor hambatan bermunculan, disebabkan oleh beberapa hal yang antara lain: Pertama, keberadaan SAD pada tahun 1976an masih banyak hidup dan tinggal tidak menetap di hutan-hutan yang berada di wilayah Kabupaten Batang Hari yang sehingga mempersulit pendataan. Kedua, kondisi akses jalan menuju tempat berkumpulnya kelompok-kelompok SAD di beberapa desa masih sulit dilalui oleh transportasi umum. Ketiga, kesulitan dalam berkomunikasi dengan SAD. Keempat, SAD masih memegang teguh adat istiadat serta tradisi dan kebiasaan-kebiasaan yang ditinggalkan nenek moyang terhadap mereka. Kelima, masalah pendekatan yang dianggap dapat merusak dan mengganggu kehidupan mereka, dan Keenam, Ketidakinginan dari beberapa SAD untuk tidak dibina oleh pemerintah.

Pemerintah telah berupaya dan bekerja keras untuk melakukan berbagai pembinaan dan pemberdayaan terhadap kehidupan $\mathrm{SAD}$, namun terkadang upaya pembinaan dan pemberdayaan tersebut mendapatkan berbagai hambatan yang seakan mematahkan semangat pemerintah untuk terus bekerja, berbagai upaya pembinaan yang dilakukan oleh pemerintah seakan terus menuai kontroversi, berbagai isu 
dan tanggapan miring terhadap pembinaan yang dilakukan pemerintah seakan-akan sudah terlanjur melekat, karena berbagai program-program pemerintah dianggap sebagai proyek yang terkesan asal-asalan.

Respon SAD terhadap pembinaan yang dilakukan oleh Pemerintah berjalan sesuai dengan harapan bagi kelompok SAD di Desa Bungku itu sendiri karena memang pada dasarnya mereka ingin dibina, respon positif tersebut disebabkan juga oleh beberapa alasan yang menurut masyarakat SAD adalah mereka berhasil keluar dari ketergantungan hutan yang kian lama kian habis akibat alih fungsi lahan. Artinya lingkungan sudah tidak mendukung lagi bagi kelangsungan hidup mereka, jika mereka tidak segera dibina lambat laun akan berdampak pada nasib anak cucu mereka jika masih terus bertahan di hutan. Selain itu program pemerintah seperti transmigrasi juga sangat mendukung di kawasan Desa Bungku tersebut sehingga terjadinya interaksi atau kontak sosial secara cepat antara warga transmigrasi dan warga SAD. Respon positif lainnya setelah mendapatkan beberapa pendidikan seperti baca tulis mereka juga merasakan lebih melek terhadap perkembangan tekhnologi.

Salah satu kelompok yang menyebutkan kepuasan mereka adalah kelompok keturunan Alam Kunci, Keturunan Betok dan kelompok Keturunan Puyang Keji, mereka hidup di sekitar kawasan perkebunan sawit Desa Bungku milik PT. Asiatic Persada. Kelompok ini diusahakan oleh Pemerintah untuk dapat tinggal di wilayah tanah milik perusahaan, dengan mendirikan pemukiman dikawasan tersebut, berbagai negosiasi yang dilakukan pemerintah terhadap pihak perusahaan membuahkan hasil bagi SAD untuk dapat hidup dalam kemandirian. Mereka telah dibina oleh Pemerintah sejak tahun 1980an kelompok Alam Kunci mulai dimukimkan pada tahun 1989. Berdasarkan diskusi dengan kelompok tersebut, awalnya mereka merupakan masyarakat yang sering berpindah-pindah sebelum maraknya penebangan hutan didaerah mereka.

Fattahuddin sebagai Ketua Lembaga Adat Kabupaten Batang Hari membenarkan proses pembinaan tersebut, dalam pendapatnya Fattahuddin (63) mengatakan banyak sekali masalah yang dihadapi SAD di Kabupaten Batang Hari sebagai contoh di Desa Bungku, kami sebagai utusan Lembaga Adat, mewakili Pemerintahan ikut berwenang menangani masalah SAD, dan kami pihak lembaga adat telah berupaya sekuat tenaga untuk meneliti, merumuskan dan menarik keputusan siapa SAD yang sebenarnya dan siapa SAD yang mengaku-ngaku (SAD palsu) dengan menggunakan rumus silsilah Nenek 4 Puyang 8 maka akan ketahuan nanti siapa SAD yang memang harus dibina untuk mendapatkan hak dan tuntutannya mengingat banyaknya kasus sengketa lahan antara Perusahaan dan warga SAD.

\section{Perubahan Sosial-Budaya}

Setiap masyarakat manusia selama hidup pasti mengalami perubahan-perubahan, perubahan hanya akan dapat ditemukan oleh seseorang yang sempat meneliti susunan dan kehidupan suatu masyarakat pada suatu waktu dan membandingkannya dengan susunan dan kehidupan suatu masyarakat tersebut pada waktu yang lampau. perubahan-perubahan masyarakat dapat mengenai nilai-nilai sosial, pola-pola perilaku organisasi, susunan lembaga kemasyarakatan, lapisan-lapisan dalam masyarakat, kekuasaan dan wewenang, interaksi sosial dan lain Sebagainya.

Perubahan-perubahan tersebut juga terjadi pada masyarakat SAD yang berada di Desa Bungku, sebelum adanya program pembinaan dari pemerintah, SAD tersebut merupakan masyarakat yang pola hidupnya tidak menetap dan kurang berinteraksi dengan masyarakat luar yang sudah lebih maju. Setelah dilakukannya pembinaan dan berbagai program pendukung lainnya seperti transmigrasi, masyarakat SAD lebih cepat berinteraksi dengan masyarakat pendatang dari pulau Jawa. Program transmigrasi di Desa Bungku dan Desa Sungai Bahar mempunyai pengaruh yang sangat besar dalam merubah cara fikir mereka. Perubahan pola fikir membuat beberapa kelompok SAD tersebut tidak mengakui lagi bahwa diri mereka merupakan salah satu keturunan dari orang Kubu.

Perubahan di bidang budaya juga sangat nyata dan jelas bagi mereka yang telah terbina. Beberapa upacara adat seperti melangun dan besale mulai ditinggalkan secara perlahan, dikarenakan sebagian besar penduduk di Desa Bungku mayoritas sudah memeluk agama Islam dan sebagian kecil memeluk agama Kristen yang dibawa oleh masyarakat pendatang, menurut Kepala Desa Bungku dan hasil penelusuran dilapangan pada tahun 2015 hanya ada tiga kelompok SAD yang memeluk Agama Kristen. Salah satu indikator keberhasilan dari upaya pembinaan menurut versi Pemerintah adalah dengan berhasilnya SAD untuk keluar dari hutan dan bisa dimukimkan, mengenal sistem dan cara bertani, hidup dalam aturan Desa, memiliki gaya hidup masyarakat umum dan indikator keberhasilan terakhir adalah mereka sudah memeluk 
agama yang diakui oleh Pemerintah. Pimpinan kelompok tradisional atau tumenggung pada masyarakat SAD di Desa Bungku sudah mulai hilang dan berganti penamaan menjadi ketua adat atau ketua suku.

\section{SIMPULAN}

Berdasarkan hasil penelitian dilapangan ditemukan juga bahwa dampak dari berbagai pembinaan yang dilakukan oleh Pemerintah telah merubah kondisi sosial dan budaya yang tidak pernah diinginkan oleh sebagian besar masyarakat SAD. Pembinaan yang tidak disesuaikan dengan minat SAD juga mengakibatkan terpecahnya SAD untuk membentuk sebuah identitas baru serta pola mata pencarian baru, seperti menjadi kuli perusahaan, tenaga penyadap karet milik warga transmigran maupun masyarakat melayu, bahkan menjadi seorang pengemis disepanjang jalan litas maupun kota. Tidak adanya lahan garapan yang diberikan bagi SAD turut menyebabkan munculnya konflik sosial antara masyarakat SAD, penguasa dan pengusaha.

\section{DAFTAR PUSTAKA}

\section{Arsip/Dokumen}

Badan Pusat Statistik Batang Hari. Bajubang dalam Angka 2014. Statistik Daerah Kecamatan Bajubang

Badan Pusat Statistik Daerah Tingkat II Kabupaten Batanghari, Batanghari Dalam Angka 1980. Batanghari: BPS Kabupaten Batanghari, 1980.

Badan Pusat Statistik Daerah Tingkat II Kabupaten Batanghari, Kabupaten Batanghari Dalam Angka 1994, Batanghari: BPS Kabupaten Batanghari, 1994.

Badan Pusat Statistik Daerah Tingkat II Kabupaten Batanghari, Kabupaten Batanghari Dalam Angka 1984, Batanghari: BPS Kabupaten Batanghari, 1984.

Badan Pusat Statistik Daerah Tingkat II Kabupaten Batanghari, Kabupaten Batanghari Dalam Angka 1988, Batanghari: BPS Kabupaten Batanghari, 1988.

Bappeda Kabupaten Dati II Batang Hari. Batang Hari Dalam Angka 1984. Kantor Statistik Kabupaten Batang Hari. 1984.

Departemen Sosial R.I. Pola Dasar Pembangunan Bidang Kesejahteraan Sosial. Jakarta: Departemen Sosial R.I. 1984.

Dinas Sosial Tenaga Kerja dan Transmigrasi Batanghari, Laporan Pola Pembinaan Masyarakat Terasing di Wilayah Kabupaten Batanghari. Lokasi Sungai Terap. Desa Sei Ruan II Maro Sebo 1994. Pemerintah Daerah Tingkat II Batanghari, 1994.

Dinas Sosial Tenaga Kerja dan Transmigrasi, Pola Dasar Pembangunan Bidang Kesejahteraan Sosial. Departemen Sosial. R.I. Jakarta, 1984.

Departemen Keuangan RI. Keuangan dan Rancangan Anggaran Pendapatan dan Belanja Negara Republik Indonesia Tahun 1981/1982. Departemen Keuangan RI. Jakarta, 1983.

Badan Pusat Statistik Jambi, Indikator Kesejahteraan Rakyat Propinsi Jambi Tahun 1994. BPS Propinsi Jambi, 1994.

\section{Buku}

Adi Prasetijo, Serah Jajah dan Perlawanan yang Tersisah. Jakarta: Wedatama Widya Sastra, 2011.

Andi Prastowo, Metode Penelitian Kualitatif. Jogjakarta: Ar-Ruzz Media, 2011.

Aqib, Zainal, Pedoman dan Aplikasi Karya Tulis Ilmiah. Bandung: Yrama Widya, 2013.

Bintoro Tjokroamidjojo, Teori dan Strategi Pembangunan Nasional Jakarta: PT. Gunung Agung, 1980.

Budhi Vrihaspathi Jauhari, Jejak Peradaban Suku Anak Dalam. Jambi: Yayasan Kopsad, 2012.

Deddy Koespramoedyo dkk, Kajian Perbandingan Program Pemberdayaan Komunitas Adat Terpencil dan Program Pengembangan Wilayah Terpadu. Jakarta: Bappenas, 2004.

Direktorat Bina Masyarakat Terasing, Pengkajian Budaya dan Lingkungan Masyarakat Terasing Propinsi Sulawesi Selatan dan Kalimantan Timur. Jakarta: Departemen Sosial R.I. 1999.

Direktorat Bina Masyarakat Terasing, Pengkajian Budaya dan Lingkungan Masyarakat Terasing Propinsi Jambi, Sulawesi Tengah, Sumatera Selatan dan Bengkulu. Jakarta: Departemen Sosial R.I. 1999.

Herman Hidayat, Politik Lingkungan. Pengelolaan Hutan Masa Orde Baru dan Reformasi. Jakarta: Yayasan Obor, 2008.

Herry Darwanto, Perbandingan Program Pemberdayaan Komunitas Adat Terpencil dan Program Pengembangan Wilayah Terpadu. Jakarta: Bappenas, 2004. 
Komite Penaggulangan Kemiskinan, Penanggulangan Kemiskinan. Jakarta: BP-PK, 2002.

Lindayanti dan Zaiyardam Zubir, "Konflik dan Integrasi dalam Masyarakat Plural: Jambi 1970-2012". Prosiding Seminar Nasional 70 Tahun Indonesia Merdeka. Jurusan Sejarah Fakultas Ilmu Budaya Universitas Andalas. 2015.

Lindayanti dkk. Jambi dalam Sejarah 1500-1942. Jambi: Dinas Pariwisata dan Kebudayaan Propinsi Jambi, 2013.

Lindayanti, Menuju Integrasi Nasional Pergolakan Masyarakat Plural dalam Membentuk Indonesianisasi. Yogyakarta: Penerbit Andi, 2013.

Louis Gottschalk, Mengerti Sejarah. Jakarta: Ui Press, 1986.

M. Nazir, Alat Perikanan Tradisional di Daerah Batanghari. Jambi: Departemen Pendidikan dan

Kebudayaan Direktorat Jenderal Kebudayaan Proyek Pembinaan Permuseuman Jambi, 1994.

Mangunhardjana, Pembinaan Arti dan Metodenya. Yogyakarta: Kanisius, 1986.

Mubyarto dkk. Masyarakat Pedesaan Jambi Menuju Desa Mandiri. Yogyakarta: UGM, 1990.

Pasurdi Suparlan, Orang Sakai di Riau: Masyarakat Terasing dalam Masyarakat Indonesia. Jakarta: Yayasan Obor, 1995.

Prasinta Dewi, Bina Masyarakat Terasing: Permasalahan dan Prospek Penelitian Masyarakat Terasing. Direktorat Bina Masyarakat Terasing Dirjen Kesejahteraan Sosial. Jakarta: Departemen Sosial R.I. 1999/2000.

Rian Hidayat. Membangkitkan Batang Terendam, Sejarah Asal Usul Kebudayaan dan Perjuangan Hak SAD Batin 9. Jambi: Yayasan Setara Jambi, 2012.

Siti Mulyani, Peran Etnografi dalam Program Pembinaan Kesejahteraan Masyarakat Terasing. Direktorat Bina Masyarakat Terasing, Departemen Sosial RI. Jakarta.1999/2000.

Soegito. Pengkajian Calon Lokasi Pembinaan Masyarakat Terasing Provinsi Jambi. Jakarta: Departemen Sosial RI. 1999.

Soerjono Soekanto dan Budi Sulistyowati, Sosiologi Suatu Pengantar. Edisi Revisi. Jakarta: PT. Raja Grafindo Persada, 2013.

Thabran Kahar, Ungkapan Tradisional Daerah Jambi. Jambi: Proyek Inventarisasi dan Dokumentasi Kebudayaan Daerah, 1982/1983.

Tirtosudarmo Riwanto, Mencari Indonesia Demografi Politik Pasca Soeharto. Jakarta: LIPI Press, 2012.

Vivi Yulaswati dkk, Masyarakat Adat di Indonesia Menuju Perlindungan Sosial yang Inklusif. Jakarta: Bappenas, 2013.

Yekty Maunati, Identitas Dayak Komodifikasi dan Politik Kebudayaan. Yogyakarta: LKis, 2004.

Zaiyardam Zubir dkk, "Jalan Terjal Membentuk Karakter Bangsa: Dialektika Petani Versus Pengusaha dan Penguasa di Sumatera Barat, Riau dan Jambi 1970-2010". Prosiding Seminar Nasional 70 Tahun Indonesia Merdeka. Jurusan Sejarah Fakultas Ilmu Budaya Universitas Andalas. 2015.

\section{Tesis, Disertasi dan Hasil Penelitian}

Anyualatha Haridison. "Perjuangan Masyrakat Lokal dan Usaha Memberdayakan Diri". Jurnal Studi Pembangunan Interdisipliner, edisi 1 Juni 2013, hal.44.

Budi Setiawan. "Tesis Kebijakan Pembangunan Sosial Masyarakat Adat Orang Rimba di Kawasan Taman Nasional Bukit Dua Belas Provinsi Jambi”. Tesis, Universitas Indonesia, Jakarta, 2010.

Fahruddin Saudagar. "Pendidikan dan Kesehatan Suku Anak Dalam di Propinsi Jambi". Makalah, Jambi: Universitas Jambi. 1993.

Johan Weintré, "Studi Organisasi Sosial dan Kebudayaan Kelompok Minoritas Indonesia: Studi Kasus Masyarakat Orang Rimba di Sumatra (Orang Kubu Nomaden”. Makalah. Yogyakarta: UGM, 2003.

Lindayanti. "Perkebunan Karet di Jambi Pada Masa Pemerintahan Hindia Belanada 1906-1940". Tesis, Universitas Indonesia Jakarta, 1993.

Muntholib. "Orang Rimbo: Kajian Struktural dan Fungsional Masyarakat Terasing di Makekal Propinsi Jambi”, Disertasi, Doktoral Universitas Padjajaran. Bandung: 1995.

Rokhdian, Dodi. “Alim Rajo Disembah, Piado Rajo Disanggah. Bentuk Perlawanan Orang Rimba Makekal Hulu Terhadap Kebijakan Zonasi Taman Nasional Bukit Dua Belas Jambi”. Tesis. Pascasarjana Universitas Indonesia, Bandung: 2012. 
Tugas Penelitian. Ferry Yanto. Universitas Batang Hari mengenai Pemahaman Sejarah Tradisional di Propinsi Jambi. Tahun 2008.

Warta Kebijakan. "Konsesi untuk Konservasi (Izin Usaha Konsesvasi Hutan)”. Bogor: Cifor, edisi No. 12, Juni 2003.

\section{Surat Kabar dan Majalah}

Aksi Post, "Terkait Rumah SAD KOPSAD Sesalkan Warsi”, Jambi: 24 Januari 2007

Bulletin Alam Sumatera, "Memulihkan Kedaulatan Kawasan Hutan", Jambi: Edisi Maret 2013

Bulletin Alam Sumatera, "Bioregion Kawasan Hidup Orang Rimba", Jambi: Edisi Agustus 2008

Bulletin Alam Sumatera, "PKMT Pembangunan yang Menyesatkan”, Jambi: Edisi Mei-Agustus 2005 